\title{
The Impact Of Fuel Price Fluctuation And Macroeconomic Variables To Airlines Performance
}

\author{
Mitra Piranti \\ ${ }^{a}$ Universitas Indonesia, Magister Management, Faculty of Economic \& Business, Jakarta, Indonesia, \\ mpiranti@gmail.com
}

Article History: Received: 10 November 2020; Revised 12 January 2021 Accepted: 27 January 2021; Published online: 5 April 2021

\begin{abstract}
The airlines industry is facing significant financial risks which arises from the changes in current economic conditions that has impacted the vulnerability of stock returns as well as its financial performance. This research primarily aims to study the effects of fuel price fluctuations and macroeconomic variables to airlines performance from both internal (represented by RoA and RoE) and market perspective (represented by airlines stock return).

Data was obtained from publicly listed airlines registered in the International Air Transport Association (IATA) with their business model classification: Low-Cost Carriers (LCC) and Full-Service Carriers (FSC). The analysis was carried out using multiple panel data regression model.
\end{abstract}

Keywords: Airline stock return, Fuel Price Fluctuation, Inflation Rate, Exchange Rate, Return on Asset (RoA), Return on Equity (RoE).

\section{Introduction}

Airline and jet fuel research have been a topic that is frequently discussed in recent years especially regarding price. Jet fuel cost proves to have an impact on an airline's capacity choice in the US. The fuel's impact in capacity choice will also have an impact on the operational side, hence it determines what type of aircraft will be used, the aircraft's load factor, and its frequency of flying (Sibdari, Mohammadian, \& Pyke, 2018).

The impact of fuel cost is inevitable for both full-service carrier (FSC) and low-cost carrier (LCC).The question regarding how the relationship would affect their stock is yet to be explored. Before we look at the impact on their stock, it will be useful to see the differences between FSC and LCC in terms of operation. On the other hand, although stock price is driven mostly by fiscal variables, the significance of macroeconomic variables cannot be excluded either (Rapach and Zhou 2013). Another study found that inflation is undeniably one of the most important macroeconomic variables considered to be linked to stock price and often influences stock price.

In addition, the dynamic linkage between exchange rate as a macroeconomic variable and return on stocks has received considerable attention from researchers around the world. Empirically, several research studies attempt to determine the impact of exchange rate on stock market. Some studies show positive effect of currency exchange rate on stock market, while others show negative. Other studies have concluded that exchange rate changes have no significant impact on the stock market.

In connection with the profitability of firms, Dayanandan and Donker (2011) discovered that the rising price of crude oil has a significant positive impact on profitability performance-in this case represented by ROE, while it has negative impact in each of the crisis periods, such as Asian crisis, 911 and US financial crisis. Moreover, crude oil price proved has a significant positive impact on the accounting performance measure (as represented by ROA) of the random effect model in energy and food sectors (Wattanatorn, Kanchanapoom (2012).

The initial idea of this study is to examine how fuel price and macroeconomic variables impact to the airlines stock price return and financial performance. Hence, this study will seek out the answer whether the fuel price, inflation and exchange rate has an effect on the airlines performance both in full-service and low-cost carrier. Here we measure airlines performance from both perspective ; market perspective in which represented by stock return and from internal financial result persepective that represented by Return on Asset (RoA) and Return on Equity (RoE). We hope this study's findings will provide some recommendations for the management of airlines in making business decisions for airlines companies as well as to become guideline for airline executives to mitigate the impact of economic changes that can affect their companies' performance. On the other hand, this study hopefully can assst investors in making investment decision and also can be a reference for regulator to develop a relevant policy on how fuel price and macroeconomic variables will have an impact in the airline industry. 
This article structured as follows. Section 1 outlines the background of this research study. Section 2 provide literature review, Section 3 provides the research method, followed by results and discussion in section 4 . Lastly, Section 5 provides conclusions on the study.

\section{Literature Review}

\section{Oil Price on Stock}

There are numerous readings that show how oil prices and their changes have shaken the economy, not only within or outside countries but also in certain industries. Hamilton (1983) stated that the upsurge of oil bill in some measure was accountable for the recession in the US. Furthermore, it made a catastrophe by jeopardizing the stock market. Campbel \& Ammer (1993) found that repercussions from fluctuations on real cash flows to changes in the oil price may explain the U.S. and Canada stock prices. The reaction in the US and Canada proved the effect of cash flow on oil price shocks. Basher \& Sadorsky (2006) found that the volatility of petroleum had a bearing on asset returns in the emerging market. Their research concluded an understanding of the intention of the positive price movement in the oil price to decrease the emerging market share prices and the exchange rate of US dollar. The impact of oil prices in the transportation sector was later found by Aggarwal, who observed that petroleum prices had a negative influence to the returns of stocks in the transportation sector and that risks are increased as oil prices. As the Aggarwal, Akhigbe, \& Mohanty research (2012), Mohanty also found that oil prices in the US Travel and Leisure Industry pose a variety of risks, particularly in six sub-sectors which include aviation industries, casino, hotels, leisure facilities, restaurants and bars, and tour and traveling. In 2015 Phan, Sharma, \& Narayan (2015) found that oil producers' stock returns are favorably influenced by shifts in petroleum prices regardless of whether the oil price is rising or falling. Changes in oil prices do not impact all market subsectors for oil products, and when they do, the effect is heterogeneous. The finding is that oil price returns have an asymmetrical effect on market returns for most sub-sectors. Sim \& Zhou (2015) have looked at the affiliation between petroleum prices and US equities. First, massive, undesirable petroleum price shocks will have a positive effect on U.S. equities when the U.S. economy performs satisfactorily. Although, undesirable oil price shocks may have an effect on the US share market, the impact of positive oil price shocks is small, suggesting an asymmetric association between petroleum prices and US equities.

Broadstock \& Filis (2014) found practical indication coming from two biggest economics countries. The finding is that oil prices responds significantly positive to aggregate demand shocks with the details : Affirmative oil production shocks unpleasantly and dramatically impact the Chinese stock exchange; Petroleum price shocks have a constant and important negative effect on the trade-weighted USD index;The US and China capital markets are optimistically linked, just as the USD index and the exchange rate are ; There is a major parallel opposite relationship between the US share market and the USD, and between the Chinese stock market and the exchange rate ; and lastly, the Chinese stock market has been more unstable and sensitive to cumulative demand and petroleum price shocks than the US stock market in latest years.

Specifically referring to the Airline Industry, later in 2018, Kristjanpoller, Concha noticed that variation in fuel rates had a consequence on daily airline prices. This result is essentially optimistic, meaning that the rise in fuel costs is accompanied by an increase in airline stock prices.

Previous research mentioned above have explored oil prices and stock market prices. However, this research will dig deeper into the actions taken by FSC and LCC industries as well as further explain the impact of oil prices.

\section{Full-Service Carrier}

In competitive advantage point of view of Porter (1980), full-service carrier concentrates in differentiation strategy while low-cost carrier concentrate on cost leadership. Due to the roots of the air travel idea prior to the 1978 deregulation act, a full-service carrier became known as the legacy airline. As the name goes, it covers more than just the core products. The service that full-service airline cover are safety, schedule, reliability, seat assignments, free baggage allowance, priority service (check-in, boarding, immigration, airport security), inflight entertainment, and reservation changes as mentioned by O'Connell, J. F., \& Williams (2012). This product also has luxury services such as comfortable seating, complimentary refreshment, newspapers and magazines, two cabin class, and lounge for business class. As a full-service carrier carry more service cost, full-service carriers need to be very careful in handling the cost. How fuel impacts full-service carriers can be seen in the operational side. The full-service carrier operates in a Hub-and-spoke network model. This network model, as observed by Marti, Puertas, \& Calafat (2015), tends to be inefficient due to high investment in the hub, resulting in hubs getting congested, delays and cancelation flight that would impact the next flight. This condition gets worse by passenger preference where they tend to buy non-transit flight as transit/transfer flights are inconvenient even in the full-service airline main hub.

In order to create more profit, full-service carrier differentiates classes in the cabin. Commonly there are three classes in a full-service carrier, which are economy, business, and first class. Azadian \& Vasigh (2019) noted that 
this differentiation, in theory, will make airline able to gain more yield in low seat load factor. Obeng \& Sakano (2012) wrote that this differentiation does not only exist in the carrier but also in the same cabin class. In the economy class, there will be many sub-classes to make sure the occupancy is high and the airline able to compete in many layers of segments. Business class also have certain differentiations to make sure airline gain more in yield. In short, this strategy is called dynamic pricing.

Beside fare differentiation, full-service carriers also try to differentiate each other as their competitive advantage strategy. One of the methods is by using Skytrax ranking as mentioned by Tsafarakis, Kokotas, \& Pantouvakis (2018).

\section{Low-Cost Carrier}

Based on competitive advantage model made by Porter (1980), airline business model is categorized into two strategies: cost leadership and differentiation. Cost leadership strategy was the main reason low-cost carriers exist. Over the years, the low-cost model has evolved. When deregulation happened in the US in 1978, the original lowcost model only covered the core product of the airline. Those core products as written by Alamdari \& Fagan (2005) were safety, schedule, and reliability. Later low-cost carriers offered more services and products. Alamdari \& Fagan (2005) also note that this hybrid type of airline is still in the same category as the low-cost carrier, but the additional products and services give the airline more flexibility in getting more revenue and covering the cost. As it is their nature to have more edge over cost dimension, low-cost carriers applies efficiency strategy to have an advantage over the price of fuel price according to Marti, Puertas, \& Calafat (2015). Low-cost airline applies this broad strategy in order to maintain their efficiency; they use younger fleet, fly a short distance, point-to-point network, high utilization aircraft, and fly in higher altitudes. In the operational side Marti, Puertas, \& Calafat (2015) mentioned that low-cost carrier flies in short distances. This type of route will make aircrafts easier to deploy and make it possible to use single aircraft type as it will heavily affect aircrew license and training. In relation to fuel, the short distance will lower the risks when load factor is less than expected.

Merkert \& Hensher (2011) noted that low-cost carrier also has a younger fleet age, normally less than 5 years old. Younger fleet means higher efficiency in terms of fuel usage, but this also means higher capital expenditure. In order to overcome this challenge, low-cost carriers will order an enormous number of fleets, especially the narrow body one, to keep the price low. Spare aircraft will be leased to another airline. Since they have a lower price due to higher orders, they will also have a margin when they lease it to another airline. Not only will they have an advantage over low capital expenditure through less fuel usage, but they will also have the opportunity to lease it to another airline. The network model of this kind of airline is point-to-point instead of the Hub-and-spoke model like regular airlines usually use as mentioned by Marti, Puertas, \& Calafat (2015). This type of network will ensure low hassle regarding passenger connection resulting in lower block hour in an airport and lower fuel usage while aircraft is on the ground. This optimum block-hour model is hard to achieve if the airline has a policy on passenger connection. Not only will the transit time be considered but also the possibility of miscommunication and other irregularities that can have a domino effect in aircraft rotation.

\section{Macroeconomic Variables}

Internal and external factors have a decisive influence on the company performance result. Internal factors include the specific characteristics of the company such as technology, innovation, and market diversification, while external factors can be based on various characteristics of the industry and variables of macroeconomic such as inflation, exchange rate, competition and another factors (Bewley, Forth \& Robinson 2010). Mazumdar (2011:6) defined macroeconomics as a branch of economics dealing with the economic aspects of the economic system as an entire, rather than with the units of microeconomics, for example individuals or organizations. In Kenneth Boulding's picturesque words, macroeconomics is concerned not with individual revenue but with national revenue, not with individual costs but with market trends, not with individual production but with national production. There are many macroeconomic factors according to Jochumzen (2010), including the GDP, inflation, and exchange rate.

Macroeconomic factors affect stock-market performance. As investors value stocks, they consider macroeconomic variables. Very important that influence the output of the share market are GDP, inflation, interest and exchange rates. Various experiments have been carried out to establish the relationship between macroeconomic factors and stock markets in the past. Hunja, Chani (2014) indicates a clear association between the stock prices and macro-economic predictor. Using Granger's causality, they find that the short-term connection among the GDP, inflation, interest and exchange rates on the stock market are undesirable. Nevertheless, it shows that there is a long-term favorable connection among the macroeconomic factors of stock prices.

\section{Performance of Airlines}

Feng \& Wang (2000) reported that airline performance studies were mostly based on operating performance instead of monetary performance. Operating efficiency has become common since metrics such as usable seat kilometers, kms sales, and load factor are calculated. Financial success has not been seen as equally critical to 
date. However, Feng \& Wang argued that in terms of profitability, liquidity and solvency, evaluating airline efficiency is essential. Metrics evaluating these aspects are important because the financial state of the airline impacts its sustainability for the long term. A performance indicator environment was developed, which makes financial ratios relevant, as it helps aviation companies to compare outcomes, profitability and short- and longrange obligations (Feng \& Wang, 2000).

\section{Financial Ratios}

Financial ratios are numerical values collected from the financial statements of the company. Financial ratio analysis is the most important technique used to evaluate the performance of a company from different aspects. Financial ratios for comparison and benchmarking purposes are determined by financial information (Saleem and Rahman, 2011). Financial ratios are considered a suitable tool to represent the company's financial condition and performance over a specific period. They also help build a strong foundation to properly establish the company's financial statements as well as profit \& loss reports (Ingram, 2009). There are several categories among financial ratios, which are (1) Profitability Ratios, such as RoA, RoE, ROCE, Net Profit Margin (2) Leverage Ratio, such as Debt to Equity Ratio, Debt Ratio (3) Market Value Ratios, such as Price to Earnings Ratio (P/E) and Earning Per Share (EPS).

The most important ratios in a company is the profitability ratio. It shows the profit gained by the company. Furthermore, the company's performance and efficiency are very important in the perspective of the investor. This can be measured by profitability ratios as it is a very crucial factor to evaluate business.

The most important thing stakeholders use to attract investors are these ratios. Bernstein (1983) explained that there are quite a few features to measure an establishment's financial performance. Profit and sales were known as two of the most widely used measurement techniques. RoE, RoA and ROCE are some ratios that is categorized in profitability ratios.

\section{Return on Asset}

RoA is a ratio that enables the company to measure profitability against its total assets. RoA can show how well the company performs as it compares the profit (net income) generated to the capital invested in assets. Higher ratio indicates that their resources are being used by more productive companies (Corporate Finance Institute, 2018).

The breakdown of the RoA formula and calculation is explained below:

$$
\frac{\text { Net Income }}{\text { Average of Total Assets }}
$$

or

$$
\text { RoA }=\frac{\text { Net Income }}{\text { Total Assets in the End of Period }}
$$

The RoA formula is the most important ratios for assessing company profitability. The success of two separate firms of the same market and scale is standard practice. It is important to consider the scale of a business and its operations in order to compare two different companies using RoA.

\section{Return on Equity}

RoE enables the company to determine how well the company is earning from stakeholder investment. This ratio is measured as a divided net income by equity of shareholders. It can also be calculated as net income multiplies through asset turnover and equity multiplier. Common Stock, Retained Earnings and Paid-in Capital are included in the equity of the shareholder, since Preferred Stock is excluded (Andrew, 2003). A low amount of RoE indicates that the company is unable to retain returns that could affect financing issues as well as increase the risk of solvency. A low amount of shareholder equity earnings means that the company is not in a good position, and this can be an external equity limit. The result of the ROE is dependent on different factors such as: the company's customer niche, product strategy, and financial decision. As Eisemann (1997) explained, each company will show some variation of behavior in the same industry.

Hypothesis 1 :

-H0 : $\beta 1=0$; Fuel Price does not affect airlines performance

-H1 : $\beta 1 \neq 0$; Fuel Price affects airlines performance

Hypothesis 2 
-H0 : $\beta 2=0$; Inflation does not affect airlines performance

-H2 : $\beta 2 \neq 0$; Inflation affects airlines performance

Hypothesis 3

- H0 : $\beta 3=0$; Exchange Rate does not affect airlines performance

-H3 : $\beta 3 \neq 0$; Exchange Rate affects airlines performance

\section{Methods}

This research uses empirical approach which is equipped with panel data base on time series and cross section. The model of this study is as follows:

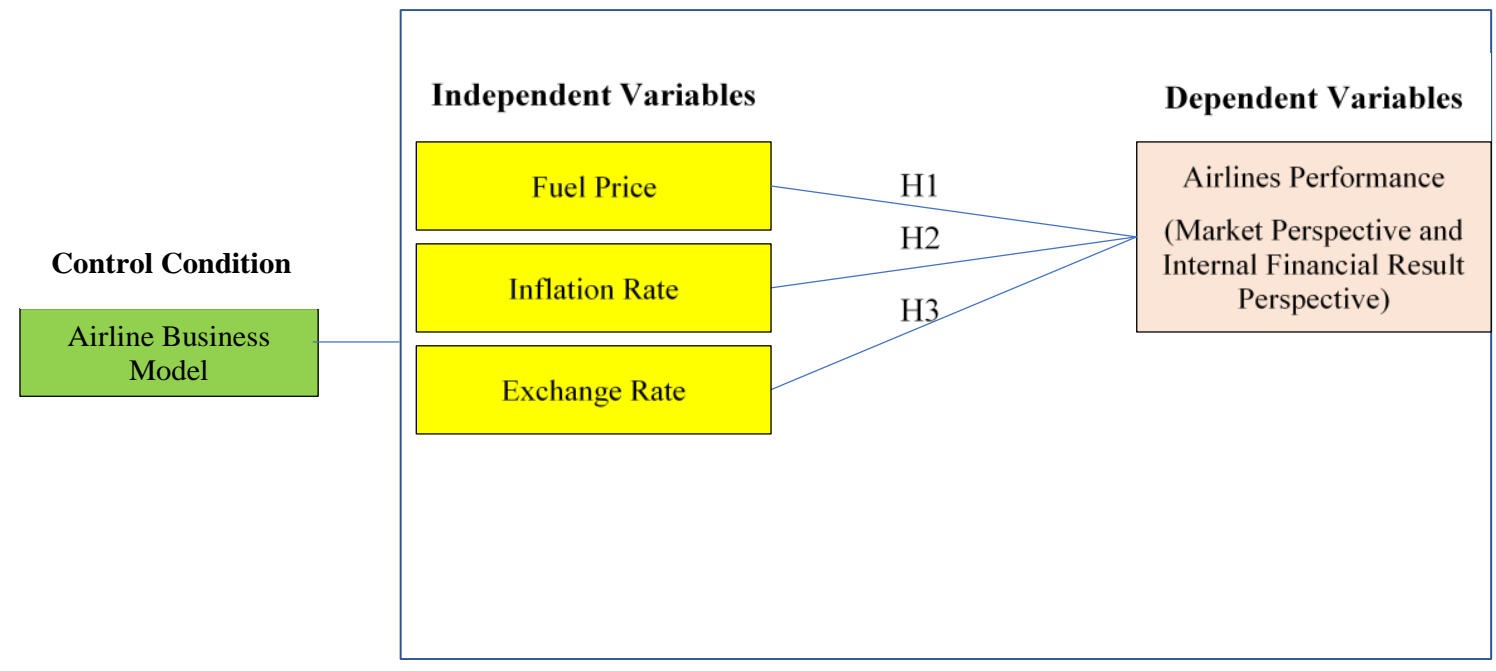

Figure 1. Research Model

Herewith the variables that represented each aspect in the model above:

1. Fuel Price : In determining the fuel price, researcher uses the percentage of Mean of Platts Singapore (MOPS) change. MOPS is the average of a set of Singapore-based oil product price assessments published by Platts that commonly used as a benchmark price for jet fuel.

2. Inflation Rate : This study uses Consumer Price Index / CPI (\%yoy) to measure inflation rate in the countries that taken as sample.

3. Exchange Rate : This study uses the currency exchange rate of the determined countries towards American dollar. In determining exchange rate variable, researcher uses the percentage of exchange rate change.

4. Airlines Performance, which is represented by threevariables: (a) Airlines Stock Return to represent airlines performance from market perspective, (b) Return on Asset and (c) Return on Equity to representairlines performance from internal perspective;

This study also consider airline business model as control condition,

\section{Data, Model and Measurements}

The research population was based on publicly listed airlines which had completed financial details and published results, and which met the following criteria (1) Listed FSC and LCC that were registered in the stock market between 2014-2018(2) Well known FSC and LCC that is registered in Skytrax (3-to-5-star airlines)

Based on determined criteria, there are 37 airlines ( 29 FSC \& 8 LCC) that eligible to be included to this research.

The following linear regression equation was used in this study:

Model 1 :

Stock Return $=\alpha+\beta 1 \mathrm{X} 1+\beta 2 \mathrm{X} 2+\beta 3 \mathrm{X} 3+\mu \mathrm{e}$

Model 2 :

$\mathrm{ROA}=\alpha+\beta 1 \mathrm{X} 1+\beta 2 \mathrm{X} 2+\beta 3 \mathrm{X} 3+\mu \mathrm{e}$ 
Model 3:

$\mathrm{ROE}=\alpha+\beta 1 \mathrm{X} 1+\beta 2 \mathrm{X} 2+\beta 3 \mathrm{X} 3+\mu \mathrm{e}$

Where:

$\alpha=$ the constant

$\beta=$ the coefficient

$\mathrm{X}_{1}=$ Fuel Price

$\mathrm{X}_{2}=$ Inflation Rate

$\mathrm{X}_{3}=$ Exchange Rate

$\mu_{\mathrm{e}}=$ Random error term

This research using a multiple panel data regression model that describes and analyse the relationship between a number of independent variables and one dependent variable. The collected secondary data were analysed using Eviews version 10 and the significance levels of $5 \%$ is used in this study.

\section{Results and Discussion}

\section{Model Selection and Testing}

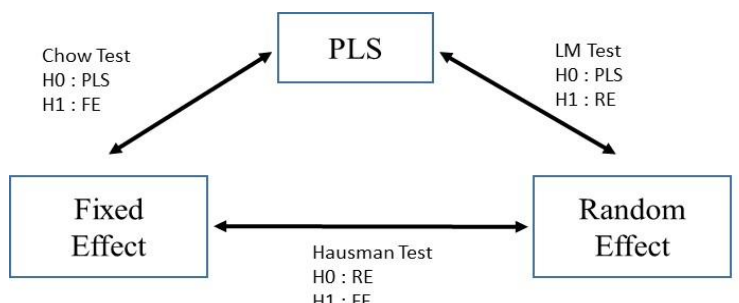

Figure 2. Estimation Model Selection

The Chow Test, Hausman Test and LM Test were conducted to select the best model for this research, with the result that for all the equation (both Full-Service Carrier and Low Cost Carrier equation), random effect was the best model.

\section{Goodness of Fit of Models}

R-square and F-test used as testing for goodness of fit (GOF) model. In the F-test for all the equations results, probability of each model are less than 0.05 , which means models all are valid to explain the dependent variable.

Table 1.Goodness of Fit (GOF) Models (FSC)

\begin{tabular}{|l|l|l|l|}
\hline & $\begin{array}{l}\text { Model 1 } \\
\text { Stock } \\
\text { Return as } \\
\text { dv) }\end{array}$ & $\begin{array}{l}\text { Model 2 } \\
\text { RoA Rate } \\
\text { as dv) }\end{array}$ & $\begin{array}{l}\text { Model 3 (RoE } \\
\text { as dv) }\end{array}$ \\
\hline R Squared & 0.083857 & 0.171116 & 0.106528 \\
\hline Adjusted R Squared & 0.059096 & 0.147657 & 0.078607 \\
\hline F-Stat & 3.386690 & 7.294247 & 3.815319 \\
\hline Prob(F-statistic) & 0.020674 & 0.000171 & 0.012456 \\
\hline $\begin{array}{l}\text { Multicollinearity } \\
\text { tests }\end{array}$ & Passed & Passed & Passed \\
\hline $\begin{array}{l}\text { Heterocscesastity } \\
\text { test }\end{array}$ & Passed & Passed & Passed \\
\hline
\end{tabular}

In the first model for Full- Service Carrier (FSC) - with Stock Return as the dependent variable - the adjusted r-squared value is 0.059096, which means all the independent variables (Fuel Price, Inflation Rate and Exchange Rate) in the model are able to explain about $5.9 \%$ of the variation in Stock Return. While in the second model using ROA as the dependent variable - all the independent variables are able to explain about $17.1 \%$ of the variation of ROAs. Similarly, in the third model, $10.65 \%$ of variations in ROE can be explained by the model. 
Meanwhile, the multicollinearity test in this study found that if the correlation between variables is small (less than 0.8 ), then the multicollinearity problem can be ignored. We then conducted the Glejser Test and found there were no heteroscedasticity problems in this research.

Table 2. Goodness of Fit (GOF) Models (LCC)

\begin{tabular}{|l|l|l|l|}
\hline & $\begin{array}{l}\text { Model 1 } \\
\text { (Stock } \\
\text { Return as } \\
\text { dv }\end{array}$ & $\begin{array}{l}\text { Model 2 } \\
\text { RoA Rate } \\
\text { as dv) }\end{array}$ & $\begin{array}{l}\text { Model 3 (RoE } \\
\text { as dv) }\end{array}$ \\
\hline R Squared & 0.010622 & 0.666632 & 0.111979 \\
\hline Adjusted R Squared & -0.071826 & 0.546620 & 0.009515 \\
\hline F-Stat & 0.128833 & 5.554692 & 1.092865 \\
\hline Prob(F-statistic) & 0.942359 & 0.000316 & 0.369713 \\
\hline $\begin{array}{l}\text { Multicollinearity } \\
\text { tests }\end{array}$ & Passed & Passed & Passed \\
\hline $\begin{array}{l}\text { Heterocscesastity } \\
\text { test }\end{array}$ & Passed & Passed & Passed \\
\hline
\end{tabular}

In the first model for Low Cost Carrier (LCC) - with Stock Return as the dependent variable - the adjusted rsquared value is -0.071826 , which means all the independent variables (Fuel Price, Inflation Rate and Exchange Rate) in the model are unable to explain the variation in Stock Return. While in the second model - using ROA as the dependent variable - all the independent variables are able to explain about $54.66 \%$ of the variation of ROAs. Similarly, in the third model, only $0.009 \%$ of variations in ROE can be explained by the model. Meanwhile, the multicollinearity test in this study found that if the correlation between variables is small (less than 0.8), then the multicollinearity problem can be ignored. We then conducted the Glejser Test and found there were no heteroscedasticity problems in this research.

The following table describes the result of regression :

Table 3 Regression Summary for Full Service Carriers : t-test

\begin{tabular}{|l|l|l|l|}
\hline \multirow{2}{*}{ Variables } & \multicolumn{3}{|l|}{ Coefficient (p-value) } \\
\cline { 2 - 4 } & $\begin{array}{l}\text { Model 1 } \\
\text { (Stock } \\
\text { Return as } \\
\mathrm{dv} \text { ) }\end{array}$ & $\begin{array}{l}\text { Model 2 } \\
\text { (ROA as dv) }\end{array}$ & $\begin{array}{l}\text { Model 3 (ROE as } \\
\mathrm{dv})\end{array}$ \\
\hline Constant & 0.0150 & 0.000 & 0.000 \\
\hline Fuel Price (X1) & $\mathbf{0 . 0 2 9 7}$ & $\mathbf{0 . 0 0 0 3}$ & $\mathbf{0 . 0 4 6 2}$ \\
\hline Inflation Rate (X2) & 0.0836 & $\mathbf{0 . 0 1 4 0}$ & $\mathbf{0 . 0 0 8 5}$ \\
\hline Exchange Rate (x3) & 0.8187 & 0.4138 & 0.7923 \\
\hline
\end{tabular}

*significant at $5 \%$ level

From the first equation, in which Stock Return is the dependent variable, only fuel price ( $\mathrm{p}$-value $=0.00297$, or prob $<0.05$ show significant results. This means fuel price significantly relates to the stock return. The correlation effect of operating lease to Tobin's Q is positive, which means that the higher of fule price, will increase airlines performance from a market perspective.

From the second equation, in which ROA is a dependent variable, fuel price ( $\mathrm{p}$-value $=0.0003$, or prob < 0.05 ), and inflation ratio ( $\mathrm{p}$-value $=0,0140$ or prob $<0.05$ ) show significant results. This means that fuel price and Inflation rate relates to the ROA. The correlation effect of fuel price and inflation rate to ROA is positive, which means the increase in fuel price and inflation rate will increase the company's performance measured by ROA.

From the third equation, in which ROE is a dependent variable, fuel price ( $\mathrm{p}$-value $=0.042$ or prob $<0.05$ ) and inflation rate ( $p$-value $=0.0085$ or prob $<0.05$ ) shows significant results. This means fuel price and inflation rate significantly affects ROE. The correlation effect is positive, which means an increased use of fuel price and inflation rate will increase the company's performance from an internal perspective measured by ROE. 
Table 4 Regression Summary for Low Cost Carrier : t-test

\begin{tabular}{|l|l|l|l|}
\hline \multirow{2}{*}{ Variables } & \multicolumn{3}{|l|}{ Coefficient (p-value) } \\
\cline { 2 - 4 } & $\begin{array}{l}\text { Model 1 } \\
\text { (Stock } \\
\text { Return as } \\
\mathrm{dv}\end{array}$ & $\begin{array}{l}\text { Model 2 } \\
\text { (ROA as dv) }\end{array}$ & $\begin{array}{l}\text { Model 3 (ROE } \\
\text { as dv) }\end{array}$ \\
\hline Constant & 0.6648 & 0.0103 & 0.0043 \\
\hline Fuel Price (X1) & 0.8226 & 0.2402 & 0.1487 \\
\hline Inflation Rate (X2) & 0.7377 & 0.6362 & 0.9390 \\
\hline Exchange Rate (x3) & 0.7943 & 0.6146 & 0.4676 \\
\hline
\end{tabular}

Based on the table above and at significant level of 5\%, it can be seen that for Low-Cost Carrier Fuel Price, Inflation Rate and Exchange Rate does not have a significat effect on stock return RoA dan RoE. It is reflected by the amount of probability as a result of t- test that show $>0.05$

Furthermore, Based on t-Test on full service and low-cost carrier above, it can also be concluded that the difference of airline business model will affect airlines performance by the changes of fuel price, inflation rate, and exchange rate.

\section{Discussion}

Based on the research objectives and the proposed hypothesis, we found that fuel price has a significant effect on the airline performance in full-service carrier but not in low-cost carrier. In full-service carrier, the fuel price has a significant negative effect on stock return, yet it has a significant positive effect on ROA and ROE. The negative effect of fuel price to stock return shows that the market views the fuel price as a financial risk factor that has a negative impact to firm value in full-service carrier. Meanwhile, the positive effect of fuel price to ROA and ROE shows the high ability of full-service carrier airlines to overcome the cost.

Meanwhile, the inflation rate has a significant effect on airline performance in full-service carrier but not in low-cost carrier. In full-service carrier, the inflation rate has a significant negative effect on ROA and ROE. The negative effect of inflation rate to ROA and ROE and the absence of the effect to stock return show that the inflation rate is a significant driver for financial performances but not for market performance in full-service carrier.

Moreover, the exchange rate does not have a significant effect on airline performance, both in full-service carrier and low-cost carrier. The lack of exchange rate effect on stock return, ROA and ROE show that the exchange rate is not a significant driver for both market and financial performances and both full-service carrier and low-cost carrier.

\section{Conclusion}

The results show that the fuel price and the inflation rate have a significant effect on the airlines performance in full-service carrier, but not in low-cost carrier. In full-service carrier, the fuel price has a significant negative effect on stock return, and it has a significant positive effect on ROA and ROE. The inflation rate has a significant negative effect on ROA and ROE. Meanwhile, the exchange rate has not a significant effect, both in full-service carrier and low-cost carrier.

However, this research might be specific for certain industry in determined cluster. For the next research, we recommend to asses additional control conditions besides business model (full-service and low-cost carrier), which theoretically also affect airlines performance, such as geographic and market share clusters as well as assessing the model of the impact of fuel price fluctuation to airline performance in other transportation sectors besides airlines.

\section{Acknowledgment}

This research was conducted with the support of Universitas Indonesia trough the PITMA-B Program 2019. We thank all the contributing parties who assisted in the completion of this research.

\section{References}

Aggarwal, R., Akhigbe, A., \& Mohanty, S. K. (2012). Oil price shocks and transportation firm asset prices. Energy Economics. https://doi.org/10.1016/j.eneco.2012.05.001

Antonakakis, Nikolaos., Gupta, Rangan., Tiwari, Aviral K. (2017). Has the correlation of inflation and stock prices changed in the United States over the last two centuries?. Research in International Business and Finance 42 Elsevier 1-8 
Broadstock, D. C., \& Filis, G. (2014). Oil price shocks and stock market returns: New evidence from the United States and China. Journal of International Financial Markets, Institutions and Money. https://doi.org/10.1016/j.intfin.2014.09.007

Gaudenzi, B., \& Bucciol, A. (2016). Jet Fuel Price Variations and Market Value: a Focus on Low-Cost and Regular Airline Companies. Journal of Business Economics and Management, 17(6), 977-991. https://doi.org/10.3846/16111699.2016.1209784

Hamilton, J. D. (1983). Oil and the Macroeconomy since World War II. Journal of Political Economy. https://doi.org/10.1086/261140

IATA. (2007). Aviation Economic Benefits. 1-40. Retrieved from https://www.iata.org/whatwedo/Documents/economics/aviation_economic_benefits.pdf.

Kristjanpoller, W. D., \& Concha, D. (2016). Impact of fuel price fluctuations on airline stock returns. Applied Energy, 178, 496-504. https://doi.org/10.1016/j.apenergy.2016.06.089

Narayan, P. K., \& Gupta, R. (2015). Has oil price predicted stock returns for over a century? Energy Economics. https://doi.org/10.1016/j.eneco.2014.11.018

Narayan P, Sharma S (2011). New evidence on oil price and firm returns. J Bank Finance 2011;35(12):3253-62

Phan, D. H. B., Sharma, S. S., \& Narayan, P. K. (2015). Oil price and stock returns of consumers and producers of crude oil. Journal of International Financial Markets, Institutions and Money. https://doi.org/10.1016/j.intfin.2014.11.010

Rozenberg, R., Szabo, S., \& Šebešćáková, I. (2014). Comparison of FSC and LCC and their market share in aviation. International Review of Aerospace Engineering. https://doi.org/10.15866/irease.v7i5.4439

Sibdari, S., Mohammadian, I., \& Pyke, D. F. (2018). On the impact of jet fuel cost on airlines' capacity choice: Evidence from the U.S. domestic markets. Transportation Research Part E: Logistics and Transportation Review. https://doi.org/10.1016/j.tre.2017.12.009

Sim, N., \& Zhou, H. (2015). Oil prices, US stock return, and the dependence between their quantiles. Journal of Banking and Finance. https://doi.org/10.1016/j.jbankfin.2015.01.013

Yun, X., \& Yoon, S. M. (2018). Impact of oil price change on airline's stock price and volatility: Evidence from China and South Korea. Energy Economics. https://doi.org/10.1016/j.eneco.2018.09.015 